\title{
The Ideologies of War and Social Class in Atonement: A Critical Stylistic Analysis
}

\author{
Doha Mahmoud Abdel-Moety \\ Tanta University, Egypt
}

The present study is concerned with the representation of ideologies in fiction. It attempts an analysis of Ian McEwan's novel Atonement and aims at revealing the ideologies of war and social class by analysing textual conceptual functions. It applies a critical stylistic analysis based on Feffies's (2010) framework. The study addresses the following questions:

How are the concepts of war and social class presented in the novel?

Which categories are used to introduce war and social class in the novel?

What is the linguistic realization of the categories selected?

What does Atonement reveal about British society and the period during which the events took place?

To what extent are McEwan's ideologies reflected in the novel?

The results of the study show that war and social class constitute an important part in the novel. There are references to them from the very beginning of the novel. They are presented ideologically through the categories of naming and describing, negating, representing actions/events/states, prioritizing, hypothesizing, implying and assuming, presenting others' speech and thoughts, and representing time, space and society. These categories employed specific linguistic realizations that helped the author achieve his purpose and influence readers. The results also reveal the way Atonement portrays the circumstances of British society before, during, and after the Second World War. Moreover, they indicate the existence of historically accurate information related to war. Finally, the results demonstrate that the representations of war and social class in Atonement are ideologically loaded. These representations reflect McEwan's own attitude toward history, war, and social class.

Keywords

Critical stylistics; ideology; British novels; Atonement; Second World War; social class, Ian McEwan 


\section{Introduction}

The relationship between ideology and language has been of interest to many researchers in linguistics. Those researchers show that "Language can only function as long as it is social and ideological" (Herman and Vervaeck 256) and that abstract and non-ideological language is not existent. In other words, all language use is "to be seen as ideological" (Hasan 439) and it is not possible to "read off" ideologies from texts since "ideologies reside in texts" (Fairclough). Researchers also show that each text reflects the ideology of those who produce it (Wodak; Van Dijk). Consequently, various studies have been conducted within the area of linguistics to reveal the hidden ideologies of texts. However, these studies have concentrated on rather specific types of discourse. They have focused on political discourse and media discourse rather than on literary texts. Thus, the representation of ideologies in literary works has not received adequate attention. Moreover, these linguistic studies have adopted a critical discourse analysis approach in their analytical framework while neglecting other approaches such as critical stylistic analysis. Therefore, the current study attempts to fill this gap by investigating a literary text which represents an example of language intended to influence readers and to create specific types of meaning (Halliday and Matthiessen). It attempts an analysis of the linguistic elements and strategies used to present Ian McEwan's ideologies conveyed in his novel Atonement. In addition, the study will apply a critical stylistic analysis based on Jeffries's (2010) textual conceptual functions that has not been adequately applied to literary works. Finally, it will attempt to identify the categories and the linguistic strategies used to convey this ideology.

\section{Previous Studies}

This section will tackle a review of the literature on three related concepts, namely, ideology, ideology and literary works, and critical stylistics. It will first discuss definitions of the term ideology in general. Then, it will provide definitions and use of ideology in literary works, particularly in fiction. Finally, it will show the concern of critical stylistics with revealing ideology in language. 


\subsection{The term "ideology"}

The term ideology can be traced back to the eighteenth-century term "idéologie" introduced by Destutt de Tracy (Van Dijk). This controversial term has gained the interest of scholars, philosophers, and researchers since the 1970s. This interest has led to various studies in different disciplines such as critical linguistics, critical discourse analysis, stylistics, philosophy, and politics. Approaches to ideology in these studies focused on three aspects, namely the psychological aspect, the sociological aspect, and the aspect of language and discourse (Van Dijk). These approaches provide different definitions and evaluations of the term. However, they all agree that ideology is essentially social. It refers to the prevailing ideas of an age and/or a society (Van Dijk). It is "a system of knowledge and beliefs or a set of assumptions used in the inferential processing of text" (Weber 12). It refers to forms of social consciousness that include political, religious, ethical and aesthetic consciousness (Eagleton 4). The researchers also indicate that ideology is manifested in all types of social practices, the most important of which is discourse. In discourse, scholars show that the creation and interpretation of all texts is ideological and aimed at supporting or reinforcing a specific way of thinking about the world. They also show that this ideological representation is very complex since it may be implicit or hidden rather than explicit. Therefore, they stress the need for a close examination of the context and the social background in addition to all levels of the text in order to interpret ideology in discourse.

\subsection{Ideology in literary works}

Ideology is evident in all literary works (Eagleton 66), which aim, according to both Marxist and non-Marxist critics, to reveal different forms of domination (Moriarty). Novels, plays, and poems work in various ways and lead readers to multiple ideological interpretations. They discuss and present serious issues and problems facing people in their lives (Farrell). In fiction, for example, "novels do not depict life, [but] they depict life as it is represented by ideology" (Davies 24). In this way, each novel "gives an interpretation of the world it represents" (Fowler 130). It can show not only the values of the author who produces it but also the values of the whole society. Novelists use language to express knowledge, opinions, attitudes and ideologies through the setting, the duration, the actions, the characters, and the theme. This presentation of ideological beliefs and conceptions comes through the author, the characters, 
or the narrator. Therefore, readers have to pay particular attention to the meaning of these aspects in relation to the novel, to the culture in which the novel is written, and to the readers in that culture (Davies). This attention will lead to an understanding of the set of values behind the narrative and an understanding of the time, the age, and the society in which the work is produced (Eagleton 5 ).

This relationship between ideology and novels has been the focus of study in narrative fiction from different perspectives such as the sociological perspective, the psychological perspective, the rhetorical perspective, the combined perspective, and the discursive perspective (Herman and Vervaeck). Each of these perspectives provides its own framework for identifying ideology in fiction. For example, in the discursive perspective, Uspensky (1973) and Fowler (1996) discuss the point of view on the ideological plane in their fourway model of point of view in narrative. In this model, the text is seen as a mediator of ideological beliefs presented by the character, the author, and/or the narrator. Recently, studies of ideology in literary works in general focused on using linguistic devices for analysing texts from a critical perspective drawing on critical linguistics and critical discourse analysis. However, these recent studies lack, according to Jeffries, the link between stylistics and critical discourse analysis. To meet this shortcoming, she calls for an approach known as critical stylistics.

\subsection{Critical Stylistics}

Critical stylistics is a sub-discipline of applied linguistics devised by Jeffries (2010). It draws its insight from stylistics, feminist stylistics, and critical discourse analysis. It provides a link between stylistics with its emphasis on linguistic devices and critical discourse analysis with its focus on the contextual features of powerful language. It is concerned with the presentation of ideology in language and aims at revealing ideologies embedded in surface and grammatical structure of texts. It employs a set of systematic and analytic tools to investigate the way linguistic choices are used to present ideologies of text producers (Jeffries 3). These linguistic choices are investigated by analysing textual-conceptual functions, which account for "the fact that texts can create specific types of meaning in a number of different ways" (Jeffries 409). The model of critical stylistics has two types of meaning, namely, textual and conceptual. These two types of meaning are closely related to the ideational function of language presented in Halliday's systemic functional 
grammar (Jeffries). They are part of the textual use of language rather than the contextual use of pragmatics. In the model, the conceptual part refers to the way the linguistic tools "try to capture what a text is doing conceptually in presenting the world" (Jeffries 409) while the textual part refers to the way these resources are used to construct the conceptual meaning (409). Therefore, the analysis of textual-conceptual functions shifts the focus from macro level analysis of context used in critical discourse analysis to micro level analysis of texts. It provides a clear framework with text analytic tools that enable analysts to find out what the text is doing conceptually and the way readers perceive the world presented in the text. Moreover, it is more comprehensive than previous models presented in critical linguistics and critical discourse analysis. Therefore, the present study will adopt this model with the aim of revealing ideology presented in one piece of narrative fiction.

\section{Research Objectives and Methodology}

The present study is concerned with the representation of the ideologies of the Second World War and social class in Atonement. These two themes are selected since they express ideologies in the novel. Moreover, it has been noted that war has not been discussed directly by English novelists (Han and Wang) and that the issue of class has received little attention among scholars studying the themes of Atonement (Fraser). The analysis starts from two assumptions: the first assumption holds that the creation and interpretation of all texts is ideological and that each text presents the world in a particular way while the second assumption asserts that in fiction, texts can help to expose society's dominant ideologies and allow readers to see these ideologies in operation.

\subsection{The Data}

The data of the present study is the novel Atonement published by Ian McEwan in 2001. Atonement is a "neo-historical" modern fiction that has been praised by critics. It has been described as a bestseller, magnificent, and a masterpiece (Wells). "It focuses on a crucial period in the history of England between 1935 and 1940" (Finney 68). Therefore, it paves the way for discussing two important ideological concepts, namely, the Second World War and social class. It is divided into four parts. Part one starts the narrative framework of the novel with the representation of the characters and the narration of 
the details of a single summer day in 1935 at the home of an upper middle class family in southern England. Part two describes the retreat of the British Army during the Second World War to Dunkirk in 1940 and part three details a London hospital receiving wounded in wartime. Finally, part four ends in the year 1999 in which readers learn that the story is narrated by one of the characters, namely Briony, in an attempt to atone for her actions against her sister Cecilia and her lover Robbie.

\subsection{Aim of the Study}

The present study aims to reveal the ideologies conveyed in the novel. It also attempts to identify the categories and the linguistic strategies used to express these ideologies. The study addresses the following questions:

How are the concepts of war and social class presented in the novel? Which categories are used to present war and social class in the novel? What is the linguistic realization of the categories selected?

What does the story reveal about British society and the period during which the events took place?

To what extent are McEwan's ideologies reflected in the novel?

\subsection{Framework of Analysis}

The theoretical approach adopted in the present study is based on Jeffries's (2010) critical stylistics model. According to Jeffries, all texts have ideas. Therefore, they all have ideologies, which can be explicit or implicit. These ideologies are exposed through linguistic choices of text producers. The model includes ten categories or tools of analysis, which can help in revealing the ideological content in the text. These categories include naming and describing, representing actions/events/states, negating, equating and contrasting, exemplifying and enumerating, prioritizing, implying and assuming, hypothesizing, presenting others' speech and thought, and representing time, space and society. The following table shows these categories and their linguistic realizations as presented in the model.

\begin{tabular}{|l|l|}
\hline Textual conceptual function & Linguistic realizations \\
\hline Naming and describing & $\begin{array}{l}\text { Choice of nouns; modification of nouns } \\
\text { through pre and post modification }\end{array}$ \\
\hline
\end{tabular}




\begin{tabular}{|l|l|}
\hline $\begin{array}{l}\text { Representing actions/events/ } \\
\text { states }\end{array}$ & Choice of transitivity process \\
\hline Negating & $\begin{array}{l}\text { Negation of a clause through negative particle; } \\
\text { negation of a word through morphology; } \\
\text { semantics and pragmatics }\end{array}$ \\
\hline Equating and contrasting & $\begin{array}{l}\text { Apposition; parallel structures; relational } \\
\text { transitivity processes; syntactic frames }\end{array}$ \\
\hline Exemplifying and enumerating & $\begin{array}{l}\text { Lists indicating hyponymous or meronymous } \\
\text { sense relations }\end{array}$ \\
\hline Prioritizing & $\begin{array}{l}\text { Positioning of information in main or } \\
\text { subordinate clauses; active and passive } \\
\text { constructions }\end{array}$ \\
\hline Implying and assuming & Presupposition and implicature \\
\hline Hypothesizing & Modality choices \\
\hline $\begin{array}{l}\text { Presenting others'speech and } \\
\text { thought }\end{array}$ & Speech and thought presentation \\
\hline $\begin{array}{l}\text { Representing time, space and } \\
\text { society }\end{array}$ & Deixis \\
\hline
\end{tabular}

(Adapted from Jeffries, 2010, 17-146)

The analysis will examine the linguistic strategies used by the author to present the ideologies of the Second World War and social class. It will identify the categories used to represent the ideologies in the novel. It will also explain the effect of the grammatical and linguistic features used in achieving the purpose of the author.

\section{Analysis of the data and discussion of the results}

\subsection{General observations}

A close examination of Atonement shows that each part in the novel is different from the other parts in its division, length, predominant themes, and language. First, part one has 14 chapters while parts two, three, and four have no chapters. Second, there are differences in the length of the four parts. Parts two, three, and four are individually and combined shorter than part one. Part one covers 187 pages while the other three parts cover 76,82 , and 21 pages respectively. Third, the themes of the novel are displayed throughout 
the parts with emphasis on particular topics in each part. War and social class are the predominant themes in part two and part three while in part one and part four innocence, guilt, atonement, forgiveness, misunderstanding, literary tradition, and identity are the predominant topics. This organization of the themes matches the choice of the division and length of the parts. Parts two and three are short and suit the immediacy and quick development of the war. Part two is intended to show the breakdown, which Robbie, the protagonist, faces and his suffering from both war and the social class structure. Similarly, the sudden change from calmness to urgency appears in part three which is short and which has no division into chapters in order to portray the abrupt change in England with the arrival of the dead and wounded to a London hospital. This observation is similar to that of Ellam (26) who emphasized that the lack of division into chapters in part two and part three adds to the disorder of the situation and increases the sense of the chaos of Robbie's thoughts. Finally, the use of language in these two parts is different from that of part one and part four. Part two and part three are characterized by the choice of specific words and the use of detailed descriptions that reveal the horrors of the war. For example, the words "Stuka attacks, bombing, refugees, machine-gun attack, retreat, heavy weaponry, damage, wound, shock, blood, filthy clothes, sweat, medical alcohol, damaged limb, lob shells, vanish, survive, shock, bury, and die" expose the atrocities of the war. In addition, the use of sub-textual dialogues in part two allows readers to delve into the consciousness of Robbie, to share his fear of the war, to know his thoughts about social class, and to perceive him as a victim. This use of language turns the novel, as noticed by Ellam (38), into a realistic story and heightens its sense of tragedy.

\subsection{Representation of ideologies in Atonement}

\section{How are the concepts of war and social class presented in the novel?}

An analysis of the novel shows that McEwan uses language to depict and present his beliefs about the war based on his father's experience of it and his attitudes toward social class. In the novel, he introduces the concepts of war and social class in a specific way. First, war means the destruction of civilization. It is a criminal, inhuman, and brutal act against innocent people. It causes damage and loss of millions of killed and wounded civilians. This image appeared in part two that describes the dead and injured people in France and in part three that details the arrival of the wounded to London Hospital. Second, the social class structure or the problem of class is an 
injustice since it is not based on equality among people. Lower middle class or working class people should have access to art and literature. They should have a society in which they may fulfil their aspirations. In other words, there should be social change that allows the existence of justice and equality for lower middle class people and there should be no reason for discrimination. This ideological presentation is organized in different ways to reflect the author's attitude toward war and social class. First, he introduces these concepts with reference to a particular time and a particular location. In part one readers come to know that the events occur in England in 1935. They also encounter war in France in part two and war in England in part three. The author's choice of this period during which the story takes place indicates the circumstances in British society, reveals aspects of the social world at this particular time in the history of England, and paves the way for a discussion of class. Second, he makes Robbie, the protagonist, a victim of both class difference and the war, which means that they are based on injustice and that they are the reason for all of the calamities in the novel.

\section{Which categories are used to present war and social class in the novel?}

The author's presentation of war and social class come in the form of linguistic choices that he makes at the level of surface and grammatical structure. These linguistic choices appeared in a number of categories that allowed him to achieve his purpose successfully. These categories work together to create an effect in the text. They include naming and describing; representing actions/events/states; negating; prioritizing; hypothesizing; implying and assuming; presenting others' speech and thoughts; and representing time, space and society.

\section{What is the linguistic realization of the categories selected?}

Each of the categories used to present war and social class has its own linguistic realization, which helps convey the meaning intended. The following section will present each of these categories in detail accompanied by illustrative examples rather than combining them together and discussing them in selected extracts from the novel.

\subsubsection{Naming and describing}

McEwan's use of language to express his opinions and attitudes on and ideologies of the concepts of war and social class come through the category of 
naming and describing. In this category, the nouns "horrors", "terror", "attacks", "bombing" and "the horror" are used to describe war. These nouns refer to observable events and carry negative meaning. They supply the exact images McEwan wants readers to have. They also constitute co-meronyms with respect to "war". They give the reader the view of war from its different perspectives and this presentation adds to the horrible image of the war. Moreover, it creates an important rhetorical power in the meronymic relationship between "war" and its putative parts. The use of the word "horrors" conveys the meaning of threat, evil actions, fear and alarming situations. It also emphasizes the evil practices in war. Similarly, social class is introduced from the very beginning of the novel through the author's choice of the proper names of the characters, which reflects the British cultural view of class bias. This finding is in line with Halliday's (29) observation that "language is used, in fiction, to project a world beyond language" and that "we use not only our knowledge of language, the meaning of words, etc., but also our general knowledge of the real world, to furnish it". This choice of proper names is also effective because "a word can always evoke everything that can be associated with it in one way or another" (de Saussure 126). This finding is similar to that of Ellam who shows that the names of Briony, Cecilia, and Robbie reflect the social class. Briony and Cecilia belong to the higher class while Robbie belongs to the lower class. Moreover, references to social class with the nouns "stupidity", "snobbery", and "strangeness" give the reader a negative image of the class structure.

In addition to nominalization, the choice of the noun phrases in which these nouns appear and the use of premodification in the form of adjectives with "negative appraisal" (Martin and White) emphasize the assumptions and the ideologies intended. Examples of these noun phrases include "the full ignominy of the retreat", "repeated episodes of terror", "dead civilization", "vanished life", "vanished boy", "ruined life", "the difficult matter of rank", and "daily stupidity". One advantage of this selection is that the property the author refers to appears like an entity rather than like a process. Another advantage is that it comes in a form that readers cannot contest or change. Finally, the use of the adjectives "dead", "ruined", and "vanished" asserts the sense of suffering. Moreover, the grouping of these related adjectives, which show differences in meaning, calls readers to think of the shading of meaning that the author intends to convey and the effect he wants to create. They help readers get the impression of Robbie as bewildered and confused. 


\subsubsection{Representing actions/events/states}

There are various and alternative ways of presenting the same event. Therefore, the choice of certain processes to present actions and events in the novel is subject to ideological interpretation. This choice of the processes demonstrates that McEwan intends to have an effect on the readers' way of seeing the information presented. Part two and part three have heavily descriptive passages that reconstruct in the reader's eye the events of the Second World War and the scene of social class. These descriptive passages come in the form of existential and relational processes. The choice of these two processes creates a psychological involvement and shows a concern with the internal condition or insight of the characters. Readers spend the whole of part two listening to Robbie become distracted. They gain access to his mind and become able to see what is going on in his head. Examples of these clauses, which come in the form of an existential process include "THERE WERE HORRORS enough" (191) and "there were Stuka attacks right over the beach they were heading toward" (231). The use of existential process emphasizes the existence of horrors and attacks. It also gives the reader the impression of a strong connection because an existential process, as Hancock (240) remarks, "presents an entity as existing without predicating anything additional about it". Similarly, there are frequent uses of relational states of being, identified by the use of the verbs "be", "seem", and "become". Some of these clauses represent the awful events of the war and the narrator's struggle to make sense of them while others encode the author's view of war and social class, which come in the form of static description. Examples of the first type of clauses, which represent the awful picture of the war include "It seemed impossible that anyone, or anything, could survive there" (187), "It seemed another man's life to him now" (204), and "Being here sheltering in a barn, with an army in rout, where a child's limb in a tree was something that ordinary men could ignore, where a whole country, a whole civilization was about to fall, was better than being there, on a narrow bed under a dim electric light, waiting for nothing" (202). Examples of the second type of clauses presenting the author's view of war and social class are "war is a collective insanity" (353) and "It was an industrial process" (189).

\subsubsection{Negating}

The author employs a number of methods of negating with reference to war and social class. These methods include grammatical and lexical ones. The former comes in the form of no, not, never while the latter includes either 
negative affixes or whole words such as "lack". Examples from the novel include "no one", "not meaningless", "never forgave", "unease", and "lacked the confidence". This use of negation is a powerful strategy used ideologically since it indicates suggestibility and it evokes positive and negative meanings. For example, the negative in the clause "THE UNEASE WAS not confined to the hospital" (251) suggests its opposite meaning in the reader's mind. It indicates that all London has a sense of unease and anxiety. Similarly, the clause " $M y$ mother never forgave you your first" (209) indicates the idea of injustice based on class difference and the "ill-preparedness of the mentality of the upper middle-class in an imperial period" (Tew 169). It also demonstrates that it is not accepted according to the class mentality of that period that ordinary people from the working class could be equal to those from the higher middle class. In the clause "They need never see the end result - a vanished boy" (190), on the other hand, the use of the negative adverbial indicates the immorality and indifference of those responsible for the war. The author chooses to tell the reader what is not the case rather than telling him/her what the case is. This usage implies that the politicians' and ordinary people's view about war contrasts with that of the author.

\subsubsection{Prioritizing}

The analysis shows that there are differences in the construction of the clause structure to present events and actions in the novel with reference to war and social class. Some events are presented at the highest level of structure while others are subordinated within the clause or the phrase. Throughout part two and part three, the author chooses to foreground and background information in a way that guides the reader to interpret the text in a specific way or to get the impression that certain elements in the sentence are more prominent than others. Moreover, he sometimes presents the information in the form of a phrase or a hedge that obscures the real message and makes it difficult to challenge. For example, in the sentence "I'm beginning to understand the snobbery that lay behind their stupidity" (209), the author chooses to background "the snobbery that lay behind their stupidity". This arrangement of information structure makes it difficult to challenge. Similarly, in the sentence, "What could be simpler, once the social element was removed?" (281), the author's choice to background "the social element was removed" makes it difficult to challenge. In other sentences, however, the author presents his idea by foregrounding information. For example, in the sentence, "The reality was all too social, he 
knew", the author presents his idea about social class bias without challenge by foregrounding information and by using the factive verb "to know", which asserts that the subordinate clause "The reality was all too social" is true. There are also instances for the use of phrases such as "A dead civilization" and " $a$ vanished boy", which appear in a way that cannot be challenged. This finding demonstrates that the arrangement of information structure, subordination, and transformations in clause structure, is used strategically in the novel to reflect the author's own view of war and social class.

\subsubsection{Hypothesizing}

The category of hypothesizing is identified through the author's use of modality, which includes signals of varying degrees of certainty about the propositions expressed and the sorts of obligations and commitments he attaches to the utterances. In presenting the concepts of war and social class, the author uses modality expressed in a variety of linguistic forms to reveal his own degree of belief in the proposition expressed. These forms include auxiliary modal verbs, semi-auxiliary modal verbs, adverbs, and conditional structures, which reflect, according to Jeffries, the author's strong degree of certainty. These expressions of modality come at different levels of structure creating various effects on readers. Illustrative examples for such usage include the following sentences from part two and part three:

A. Epistemic modality through auxiliary modal verbs What could be simpler, once the social element was removed? (281)

Their love would have space and a society to grow in. (213)

B. Epistemic modality through auxiliary modal verbs and adverbs "It must have been a big machine-gun attack, perhaps from the air, perhaps an ambush." (187)

C. Epistemic modality through semi-auxiliary verbs "They need never see the end result - a vanished boy." (19o)

"It seemed impossible that anyone, or anything, could survive there." (187)

D. Epistemic modality through a conditional structure "Half a dozen twenty-five-pounder guns were piled beyond the ditch, as if swept up there by a heavy bulldozer." (207) 
In addition, the author employs epistemic modality and words of "estrangement" (Fowler) such as "seemed", "appeared", and "perhaps". This usage portrays the narrator's uncertainty about events and catastrophes of the war and his attempt to make sense of what he sees. It also foregrounds Robbie's concepts of war and provides his own viewing position, which the author wants readers to share. It also characterizes the gloomy setting and the violent events of the war. Illustrative examples of this usage include "It seemed to be", "it appeared to be", "perhaps a railway man's cottage rebuilt after the last time", "A piece of shrapnel perhaps", "The scraps of cloth, he was beginning to think, may have been a child's pajamas", and "It may have been blood, or some other fluid ...".

Finally, the analysis shows the existence of propositions in the novel containing no modality. The use of these propositions allows the author to "claim objective certainty ... for something that is in fact a matter of opinion" (Halliday 340). Moreover, it helps him present information as a fact (Fairclough 129). Examples for the use of these propositions known as categorical assertions are the sentences "It was an industrial process" and "The reality was all too social, he knew" (157) in which the author presents his view confidently as a universal reality.

\subsubsection{Implying and assuming}

There are embedded assumptions and implications in the novel. These assumptions and implications include pragmatic elements and textual elements. The pragmatic elements come in the form of implicit meanings such as the reason for sending Robbie to war and the reason for Briony's joining the London hospital, which refer to the injustices of war and social class. Robbie, the innocent victim, is sent to war to exonerate himself and this is ironic since he committed no crime. As for Briony, her work as a nurse is intended as a form of humiliation for this upper middle class character. Textual elements, on the other hand, are evident in the images described and presented by the author. His view of the brutality, suffering, and torture of the war appears in the description of the details of the physical sensations of hunger, thirst, and fear that Robbie, the protagonist, faces on the road to Dunkirk. Examples for these images include "he was too thirsty to chew", "He was too thirsty to wait about", and "His tongue was large in his mouth and all he could think of now was finding a drink" (210). Moreover, the awful events of the war are presented in heavily foregrounded references to visual appearance as 
in the following extract which represents, according to Brown, "the novel's most powerful indicator of war's horror" (2). In this extract, McEwan implies the horrible sight of the war by describing a scene that Robbie encounters on his way to evacuation.

... he saw it. ... It was a leg in a tree. A mature plane tree, only just in leaf. The leg was twenty feet up, wedged in the first forking of the trunk, bare, severed cleanly above the knee. From where they stood there was no sign of blood or torn flesh. It was a perfect leg, pale, smooth, small enough to be a child's. The way it was angled in the fork, it seemed to be on display, for their benefit or enlightenment: this is a leg. (191)

Social class is also referred to implicitly as in the sentences "The reality was all too social" (157) and "Had he always taken for granted the strangeness of these names" (187). In the first sentence, the author expresses his belief in the injustice of class differences by the adverb "too", which implies a negative meaning while in the second sentence he refers to the differences that appear even in the names of upper class persons by using the word "strangeness". The author's presentation of the assumptions in this implied way makes them difficult to contest.

\subsubsection{Presenting others' speech and thoughts}

There are varied modes of quoting, reporting and narrating speech, thought and discourse in the novel. However, in presenting the concepts of war and social class, McEwan uses the modes of free direct speech, free direct thought, free indirect thought and free indirect discourse. Free direct speech and free direct thought come with reference to social class while free direct thought, free indirect thought and free indirect discourse appear with reference to war. Free direct speech is evident in Cecilia's words to Robbie saying "Now that I've broken away, I'm beginning to understand the snobbery that lay behind their stupidity" (149). Free direct thought, on the other hand, refers to Robbie's speech to himself, which gives the "thoughts conscious value" (Leech and Short). This usage is in the following example in which Robbie's view of class difference comes in the form of contemplation "... you walked across the land until you came to the sea. What could be simpler, once the social element was removed? ... The reality was all too social" (157).

Similarly, with reference to war, Robbie expresses his views through free direct thought in "... a whole country, a whole civilization was about to fall ...". Free indirect thought is identified in extensive accounts of Robbie's thought in "He was thinking ... about the indifference with which men could lob shells into a landscape 
..., "It was an industrial process", "They need never see the end result - a vanished boy" "Vanished" and in "It seemed another man's life to him now. A dead civilization". It has also been observed that there is a combination of free indirect thought and free indirect discourse with reference to war. An example of this usage comes in referring to the great change that the war has made. The war changes the world fundamentally "before as significant as B.C. and A.D. Before prison, before the war, before the sight of a corpse became a banality" (213).

The choice of these modes to present the concepts of war and social class can be considered ideological because it influences the readers' way of receiving and interpreting texts. It is "a powerful strategy for writers to convey specific meanings" (Caldas-Coulthard 69). In other words, the author's choice of the mode of presentation depends on the way he intends to convey meaning. Combining features of quoted and reported speech allows the author to express stance, thought and speech in an unlimited way. For example, "the snobbery that lay behind their stupidity" serves to put a distance between the opposite views of class difference. Similarly, the use of free and direct mode helps the author make generalizations in the presentation of thought as in "the reality was all too social" (157) while the use of free indirect discourse with free indirect thought leads readers to sympathize with Robbie. Moreover, it presents views and concepts to readers in a way that does not allow them to check their truthfulness.

\subsubsection{Deixis as a means of representing time, space and society}

The author used deictic words to present time, space and society. Deictic words are words whose meanings depend on the context in which they are used. They include words for place, time, tense, and person. They have two main functions. First, they create "deictic projection" (Jeffries 149), which enables readers to place themselves in the position of the author. Second, they help the author occupy the "deictic centre" of the text. In the data analysed, the author employs deictic words with reference to war and social class. This employment reflects the position where the author wants to place himself and readers. For example, the use of the word "here" in "Being here, sheltering in a barn, with an army in rout..." gives readers a sense of being in the war and emphasizes its existence. Similarly, the use of the pronouns " $I$ " and "we" causes readers to feel close to Cecilia, Robbie, the author, the British Army and its allies while the use of "they" and "their" leads readers to feel distant from Cecilia's family, 
the German Army, and the politicians responsible for the war. An example for such usage is in the following two extracts in which readers feel distant from the concept of class difference referred to as "their" in "I'm beginning to understand the snobbery that lay behind their stupidity" and "let everyone else adjust their thinking" (164). Another example of the use of deictic words in the form of pronouns is in "We'll be back to throw them out" and in "He had seen their own RA units at work, tightly knit groups, working all hours, proud of the speed with which they could set up a line, and proud of their discipline, drills, training, teamwork. They need never see the end result - a vanished boy" (190). The author also employs tense to indicate that certain concepts are distal from both the author and the readers as in "The reality was all too social" (157), "It was an industrial process", and "There were horrors enough".

\section{What does the novel reveal about the period of the war and about British society?}

Atonement is a historical novel that presents a critical period in the history of England. It describes the events of the most destructive war in the history of the world, namely the Second World War. It details the retreat of the British Army to Dunkirk in 1940 and the arrival of wounded to a London hospital. The author focuses on providing historically accurate information for this period. He also provides many details, places and vocabulary related to the period. The details include the descriptions of the horrors of the war, the sufferings of the wounded, from civilians and officers, and the preparations in a London hospital and the arrival of wounded there. The following two examples demonstrate some of these details.

Ex. 1. "They passed the walking wounded who could go no further. They sat like beggars at the side of the road, calling out for help, or for a mouthful of water" (177).

Ex. 2. "The year before, just after war was declared, the wards on the top floor had been closed down completely as a protection against bombing. The operating theatres were now in the basement. The ground-floor windows had been sandbagged, and every skylight cemented over" (195).

Places mentioned in the novel include France, Dunkirk, Rotterdam, Tottenham Court Road, Arras, Verdun, Aldershot, Whitehall, Liverpool, Birmingham, Cherbourg, Alder Hey Hospital, and Balham. As for the vocabulary related 
to war, it includes "British troops, evacuation, Dunkirk, Stuka attacks, Royal Army Forces, British Expeditionary Force, the Royal Navy, air raids, gas masks, bombing, air raids, trauma, bombs, shells, and machine guns".

These details, places, and vocabulary of war are not confined only to part two and part three. There are references to war throughout the whole novel. For example, in part one, the author expresses the tensions and anxieties felt about the outbreak of war in an exchange between two characters: "Because they'll be fighting for their country" and in "Perhaps there will be one (a war)". Similarly, in part four, many places are mentioned with reference to the years of the war. These places include the Imperial War Museum, Dunkirk, St. Thomas' Hospital, Alder Hey Hospital, and the Royal East Sussex Hospital. This finding is similar to that of Brown and Ellam who observe that the theme of war occupies the entire novel from the very beginning. They notice that there are allusions to war in part one with respect to the work of Jack Tallis and Paul Marshall.

The novel also reveals many features of British society before, during, and after the war. Class difference and women's social roles are clear from the very beginning of the novel. Readers see the division of British society into two classes based on wealth: upper middle class, and lower middle class or working class. Upper middle class or the privileged class live in luxury as seen in the house of the Tallis family and in the way in which they spend their time. The lower middle class, on the other hand, live a hard life reflected in the work they have to do in the Tallis house and in the description of the bungalow in which they live. Class difference also appears in the way lower middle class characters are looked at in the novel, particularly by Emily Tallis who represents, as Carlbom noticed, the class mentality of the 1930 .

The character of Emily Tallis, the mother and the homemaker, is also an example of a typical role for women in the 1930s. Her only job is to stay home and to look after her children. She appears in the novel as a passive observer thinking of her children's future, her husband, her sister, and the events around her. Other references to women's social roles include the idea that they do not have equal rights in education and the workforce when compared to men. These roles change with the declaration of war and the training of women in nursing. In the last part of the novel, readers encounter changes in British society or contemporary society regarding class. Characters who made money from the war such as Paul Marshal possess rank in society and lead a privileged life. Paul Marshal got the rank lord and appeared as one of the aristocratic 
class with a high position in society. However, readers also encounter a change in class mentality exemplified in Briony when meeting an Indian taxi driver "It is quite impossible these days to assume anything about people's educational level from the way they talk or dress or from their taste in music. Safest to treat everyone you meet as a distinguished intellectual" (342).

\section{To what extent are McEwan's ideologies reflected in the novel?}

The presentation of war and social class in the novel is not in the form of a historical narrative. It is ideologically loaded and ideologically manipulative. It reflects McEwan's own attitude toward history, war, and social class. With respect to history, McEwan presents a reinterpretation of the past, drawing attention to the traumatic and severe events that affected Britain during and after the Second World War as noticed by Finney (12). In addition, he presents in the novel the lasting effects of the war on the British people and British society, hoping to prevent it from happening again. This is because McEwan is an anti-war activist. For him, war means suffering, terror, horror, and the destruction of civilization. War affects, influences, and damages the lives of innocent people. It is "an industrial process" and a "collective insanity" (McEwan 353). This view is expressed in the novel explicitly and implicitly. It is expressed explicitly through grammatical categories and lexical choices while it appears implicitly through irony referring to the injustices of war. An example of such irony comes with reference to Robbie's participation in the war to exonerate himself from a crime that he did not commit. This ideology is directly influenced by McEwan's "father's experiences during the Second World War" (Han and Wang 137).

Similarly, McEwan is against the injustices and inequalities of social class. For him, social class refers to differences between people due to socioeconomic markers. In the novel, the characters are symbols of class differences. Robbie, the son of the charlady, represents the working class. He lives in a bungalow and is referred to as the "son of a humble cleaning lady". The Tallis family represents the upper middle class and Paul Marshall represents the postwar ruling class. McEwan portrays the social markers of these classes in the grammatical and lexical choices of the descriptions of housing, clothing, the spending of time, and even in the distinction between the city and the countryside. McEwan then portrays the suffering of Robbie, allowing readers to share his viewpoint and feel sympathy for him. Thus, McEwan's rejection of class-biased and class-based perspectives is evident in the novel. He shows that, as Carlbom (1) observes, "literature can pave the way for overcoming 
class differences through sympathy and identification". This ideology of class difference has also been introduced in McEwan's other novels, such as Saturday (2005). An interest in political, historical, and social issues has been the focus of McEwan's works since the 1980s, as noticed by Wells.

\section{Conclusion}

The present study investigates the representation of war and social class in Atonement. The study adopts a critical stylistic analysis based on Jeffries's (2010) model of textual conceptual functions. The results of the study show that war and social class constitute an important part in the novel. McEwan presents these two concepts using the categories of naming and describing, representing actions/events/states, negating, prioritizing, hypothesizing, implying and assuming, presenting others' speech and thoughts, and representing time, space and society. Each of these categories has its own linguistic realization and function in the novel. The category of naming and describing is identified in the author's choice of words, nouns, noun phrases and adjectives. Actions, events and states are presented through the author's choice of existential and relational processes, which are selected to create a psychological involvement and to show a concern with the internal condition of the characters. Negating is expressed through adverbial, morphological, and lexical words. Prioritizing appears in the author's choice to foreground and background information in the construction of the clause structure. This technique leads readers to interpret the text in a specific way and/or to get the impression that certain elements in the sentence are more prominent than others. The category of hypothesizing is identified through the author's use of modality expressed in a variety of linguistic forms that include auxiliary modal verbs, semi auxiliary modal verbs, adverbs, and conditional structures. Implicature comes in the form of embedded assumptions and implications, which include pragmatic elements and textual elements. The pragmatic elements come in the form of implicit meanings while textual elements are in the images described and presented by the author. In the category of presenting others' speech and thought, McEwan uses the modes of free direct speech, free direct thought, free indirect thought and free indirect discourse. Free direct speech and free direct thought come with reference to social class while free direct thought, free indirect thought and free indirect discourse appear with reference to war. Finally, the author uses deictic words for place, time, tense, and person to 
represent time, space, and society. This usage creates "a deictic projection" and helps the author occupy the "deictic centre" of the text. Moreover, it makes readers conscious of the temporal and spatial setting.

In addition, the results of this study demonstrate that the author's choice of the period during which the story takes place portrays British society at the time and paves the way for a discussion of class. The novel reveals circumstances and features of the period during which the events take place. It details the events of the most destructive war in the history of humanity, particularly the retreat of the British Army to Dunkirk and the arrival of wounded to a London hospital. The author focuses on providing historically accurate information about this period. He also provides many details, places and vocabulary related to the period. Moreover, the novel reveals many features of British society before, during, and after the war with respect to class differences and women's social roles. Finally, the results of this study show that the presentation of war and social class in the novel does not come in the form of a narrative historian. It is ideologically loaded and is subject to ideological interpretation. It reflects McEwan's own attitude toward history, war, and social class.

\subsection{Suggestions for future research}

The present study examines the representation of the ideologies of war and social class in Atonement from a critical stylistic analysis perspective. Similar investigations can be adopted to the ideology of war and social class in Atonement from a critical discourse analysis perspective or from a pragmatic perspective. Studies may also focus on revealing McEwan's ideologies based on other concepts presented in his novels such as socio-political issues. Other studies may compare linguistic strategies used by different authors to present war and/or social class. Finally, studies may compare the representation of ideologies by authors of other literary works cross culturally.

\section{Works Cited}

Brown, Catherine. War and Peace in Ian McEwan's Atonement. 2010. Web.

20 June 2017. <http://catherinebrown.org/wordpress/wp-content/ uploads/2014/o3/Perm-Atonement.pdf>.

Caldas-Coulthard, Carmen Rosa. Reporting Speech in Narrative Discourse: Stylistic and Ideological Implications. 1992. Web. 12 May 2017. 
$<$ https://periodicos.ufsc.br/index.php/desterro/article/ download/.../811>.

Carlbom, Carolina. The Complexity of Class: A Study of Ideology and the Power of Literature in Ian McEwan's Narrative. 2009. Web. 15 May 2017.

$<$ http://lup.lub.lu.se/luur/download?func=downloadFile\&recordOId=141 5099\&fileOId=1415118>.

Davis, Lennard. Resisting Novels: Ideology and Fiction. New York: Methuen, 1987. Print.

Eagleton, Terry. "Ideology, fiction, narrative." Social Text, no. 2. 1979. Web. 8 April 2017. <http://links.jstor.org/sici?sici=0164-2472\%28197922\%29o\% 3 $\mathrm{A}_{2}{ }_{3} \mathrm{C}_{2} \%_{3} \mathrm{AIFN}{ }_{3} \mathrm{E}_{2.0 . \mathrm{CO}}{ }_{3} \mathrm{~B}_{2}-\%_{23}>$.

---. Marxism and Literary Criticism. London: Routledge, 2002. Print.

Ellam, Julie. Ian McEwan's Atonement: A Reader's Guide. London: Bloomsbury, 2009. Print.

Fairclough, Norman. Language and Power. London: Longman, 1989. Print.

--. Critical Discourse Analysis. London: Longman, 1995. Print.

Farrell, James T. "Literature and Ideology." New International. Vol. 8 No. 4. May 1942: 107-111. Print.

Finney, Brian. "Briony's Stand against Oblivion: The Making of Fiction in Ian McEwan's Atonement." Journal of Modern Literature, 3. 2004. Web. 8 January 2017. <https://wilcoxenglishwiki.wikispaces.com/file/view/Brion ys+Stand+Against+Oblivion.pdf $>$.

--.. English Fiction since 1984: Narrating a Nation. New York: Palgrave Macmillan, 2006. Print.

Fowler, Roger. Linguistic Criticism, (2 ${ }^{\text {nd }}$ edition). Oxford: Oxford University Press, 1996. Print.

Fraser, Ian. "Class Experience in McEwan's Atonement." Critique: Studies in contemporary fiction. Vol. 45 No. 4. 2013: 465-477. Print.

Halliday, Michael Alexander K. "Linguistic Function and Literary Style: An Inquiry into William Golding's The Inheritors." Literary Style: A Symposium. Ed. S. Chatman. New York, NY: Oxford University Press, 1971. 330-68. Print.

--. An Introduction to Functional Grammar. London: Edward Arnold, 1985. Print.

Halliday, Michael Alexander K. and Christian Matthiessen. An Introduction to Functional Grammar (3rd edition). London: Longman, 2004. Print.

Han, Jie and Zhenli Wang. "Postmodern Strategies in Ian McEwan's Major Novels." Advances in Literary Study 2. 2014. Web. 8 January 2017. 
<http://dx.doi.org/10.4236/als.2014.24020>.

Han, Jie and Pei Wang. "The Experimental Techniques in Ian McEwan's Atonement." Open Fournal of Social Sciences 3. 2015. Web. 8 April 2017. <http://dx.doi.org/10.4236/jss.2015.36024>.

Hancock, Craig. Meaning-Centered Grammar: An Introductory Text. London: Equinox Publishing Ltd, 2005. Print.

Hasan, Ruqaiya. "Globalization, Literacy and Ideology." World Englishes. Vol. 22 No. 4. 2003: 433-448. Print.

Herman, Luc and Bart Vervaeck. "Ideology and Narrative Fiction." Handbook of Narratology. Eds. Peter Hühn et al. Vol. 1 ( $2^{\text {nd }}$ edition). Germany: De Gruyter, 2014. 253-269. Print.

Jeffries, Lesley. Textual Construction of the Female Body: A Critical Discourse Approach. Basingstoke: Palgrave Macmillan, 2007. Print.

---. Critical Stylistics: The Power of English. London: Palgrave Macmillan, 2010. Print.

--. Critical Stylistics. The Routledge Handbook of Stylistics. Ed. M. Burke. London: Routledge, 2014. 408-420. Print.

Leech, Geoffrey N. and Mick H. Short. Style in Fiction: A Linguistic Introduction to English Fictional Prose ( $2^{\text {nd }}$ edition). London: Longman, 2003. Print.

Martin, J. R. and P. R. R. White. The Language of Evaluation: Appraisal in English. New York: Palgrave Macmillan, 2005. Print.

McEwan, Ian. Atonement. London: Cape, 2001. Print.

Moriarty, Michael. "Ideology and Literature." Fournal of Political Ideologies, 11:1. 2006: 43-6o. Print. DOI: 10.108o/13569310500395875

Saussure, Ferdinand de. Course in General Linguistics. Eds. Charles Bally and Albert Sechehaye, in collaboration with Albert Riedlinger. Translated by Wade Baskin. London: Fontana/Collins, 1974. Print.

Tew, Philip. The Contemporary British Novel. London: Continuum, 2004. Print.

Uspensky, Boris. A Poetics of Composition. The Structure of the Artistic Text and Typology of a Compositional Form. Berkeley: University of California Press, 1973. Print.

Van Dijk, Teun A. Ideology: A Multidisciplinary Approach. London: Sage Publications Ltd, 1998. Print.

--.. "Discourse, Ideology and Context." Folia Linguistica, 35(1-2). 2001: 11-40. Print.

--. Politics, Ideology, and Discourse. Amsterdam: Elsevier Ltd, 2006. Print.

Weber, Jean Jacques. Critical Analysis of Fiction: Essays in Discourse Stylistics. 
Amsterdam: Rodopi B. V., 1992. Print.

Wells, Lynn. Ian McEwan: New British Fiction. Hampshire: Palgrave Macmillan, 2010. Print.

Wodak, Ruth (ed.). Language, Power, and Ideology: Studies in Political Discourse. Amsterdam: John Benjamins, 1989. Print.

DOHA MAHMOUD ABDEL-MOETY is an Assistant Professor of Linguistics at the Department of English Language and Literature, Faculty of Education, Tanta University, Egypt. The PhD dissertation was "Rhetorical Structure of Introductions to English and Arabic Social Science Research Articles: A CrossLinguistic Study". Recent publications include researches in reading strategies, critical discourse analysis, rhetorical analysis, historical and semantic analysis, and metadiscursive analysis.

d.mahmoud@edu.tanta.edu.eg 